\title{
Meningkatkan Hasil Belajar IPA Materi Elektrostatis melalui Pembelajaran Berbasis Quipperschool pada Peserta Didik IX-A SMPN 1 Kota Tasikmalaya Tahun Pelajaran 2018/2019
}

\author{
Siska Nurhadi ${ }^{*}$ \\ ${ }^{1}$ SMP Negeri 1 Kota Tasikmalaya, Kota Tasikmalaya, Indonesia \\ *e-mail korespondensi: siekanurhadi@gmail.com \\ (masuk: 8-12-2019; revisi: 20-12-2019; diterima:31-12-2019)
}

\begin{abstract}
Abstrak: Berdasarkan kondisi di SMP Negeri 1 Kota Tasikmalaya, khususnya di kelas IX-A perlu dilakukan perbaikan dalam proses pembelajaran IPA. Data yang ada menunjukkan rata-rata ulangan belum mencapai KKM. Tujuan penelitian ini untuk mengetahui peningkatan hasil belajar peserta didik kelas IX-A SMP Negeri 1 Kota Tasikmalaya tahun pelajaran 2018/2019 melalui penerapan pembelajaran berbasis quipperschool pada materi elektrostatis dan mengetahui peningkatan aktivitas peserta didik kelas IX-A SMP Negeri 1 Kota Tasikmalaya tahun pelajaran 2018/2019 selama mengikuti pembelajaran melalui penerapan pembelajaran berbasis quipperschool pada materi elektrostatis. Penelitian menggunakan metode Penelitian Tindakan Kelas. Teknik pengumpulan data yang digunakan dalam penelitian ini dengan melaksanakan ulangan harian setiap akhir siklus, memberi tugas kelompok, tugas individu secara online, melaksanakan observasi, dan menyebarkan angket. Subjek penelitian berjumlah 32 orang peserta didik di kelas IX-A SMP Negeri 1 Kota Tasikmalaya tahun pelajaran 2018/2019. Berdasarkan hasil penelitian, pengolahan dan analisis data serta pengujian hipotesis tindakan yang telah dilakukan dalam penelitian ini, diperoleh simpulan bahwa penerapan pembelajaran berbasis quipperschool pada materi elektrostatis dapat meningkatkan hasil belajar peserta didik, terdapat peningkatan aktivitas peserta didik selama mengikuti penerapan pembelajaran berbasis quipperschool pada materi elektrostatis.
\end{abstract}

Kata kunci: elektrostatis, hasil belajar IPA, quipperschool

\section{Pendahuluan}

Di era globalisasi saat ini, sistem pembelajaran konvensional di sekolah saat ini dinyakini kurang efektif, konsep-konsep kemampuan otak, kecerdasan, dan kreativitas telah berkembang dengan pesat seiring dengan kemajuan dalam bidang teknologi dan komunikasi.

Teknologi Informasi dan komunikasi menjadi kebutuhan yang mendasar dalam menentukan kualitas dan efektifitas proses pembelajaran. Dryden dan Vos (2003) menyimpulkan dari hasil penelitian mereka bahwa dalam sistem pendidikan yang terbukti berhasil, citra diri ternyata lebih penting dari materi pelajaran.
Dengan demikian, konsep pendidikan masa depan ialah diarahkan kepada bagaimana membangkitkan gairah siswa untuk belajar secara menyenangkan (how student learn). Salah satu pendekatan dan metode yang dapat digunakan untuk meningkatkan aspek tersebut ialah dengan pemanfaatan information and communication technology (ICT) dalam proses pembelajaran. Mean (1993) dalam Suryadi $(2007 ; 91)$ menjelaskann bahwa kebutuhan masyarakat persekolahan untuk memanfaatkan teknologi dalam pembelajaran merupakan bagian dari reformasi pembelajaran. Selain membantu menciptakan kondusi belajar yang 
kondusif bagi siswa, peran penting dari teknologi informasi dan komunikasi dalam proses pembelajaran adalah menyediakan seperangkat media dan alat (tool) untuk mempermudah dan mempercepat pekerjaan siswa, serta tentu saja memberi keterampilan penggunaan teknologi tinggi (advance skill) (Suryadi, 2007;92). Selain itu, antara siswa dan sumber-sumber belajar dapat terjadi kapan saja dan di mana saja tidak terbatas oleh ruang dan waktu (space and time), serta proses penyampaian dan penyajian materi pembelajaran maupun gagasan dapat menjadi lebih menarik dan menyenangkan.

Perkembangan teknologi yang sangat pesat ini, harus selaras dengan peningkatan mutu sumber daya manusia agar arah perkembangan ilmu pengetahuan dan teknologi dapat menuju sasaran yang tepat. Seyogyanya para guru mencurahkan perhatian yang seksama dalam peningkatan mutu sumber daya manusia, khususnya dalam melihat permasalahan-permasalahan perkembangan di dalam proses pembelajaran, peserta didik maupun bahan ajar yang diajarkan.

Capaian hasil proses pembelajaran IPA di SMP Negeri 1 Tasikmalaya khususnya di kelas IX-A belum mencapai Kriteria Ketuntasan Minimal (KKM) ditandai perolehan ratarata ulangan harian dan minat serta semangat belajar yang menurun, kemampuan peserta didik dalam proses menghitung dan menganalisa soal sangat terbatas. Dari aspek pendidik terhadap materi yang susah juga media pembelajaran yang kurang memadai misalnya pada materi listrik statis. Kurangnya minat belajar IPA juga dipengaruhi oleh karena mata pelajaran IPA dibelajarkan dengan cara yang begitubegitu saja dalam artian membosankan bagi peserta didik. Permasalahan tersebut perlu disikapi dengan memberikan rangsangan dengan media yang berbasis ICT, karena dengan memberikan media berupa ICT maka peserta didik akan termotivasi, tertantang, menyenangkan, terinspirasi dan interaktif menurut Degeng
(2005) Guru besar pada universitas PGRI Surabaya. Berdasarkan uraian di atas dipandang penting untuk dilakukan penelitian tindakan kelas dengan menggunakan pembelajaran berbasis ICT dengan media Quipperschool.

Reformasi pendidikan diluncurkan dengan tujuan untuk menyesuaikan bidang pendidikan dengan perubahan dan perkembangan dalam bidang sains dan teknologi, khususnya teknologi informasi dan komunikasi (TIK) Pengertian belajar sudah banyak dikemukakan oleh para ahli psikologi termasuk ahli psikologi pendidikan, banyaknya pengertian belajar tersebut akan mempengaruhi pemahaman guru dalam perencanaan dan pelaksanaan kegiatan belajar mengajar.

Menurut pengertiannya, belajar ialah suatu proses usaha yang dilakukan seseorang untuk memperoleh suatu perubahan tingkah laku yang baru secara keseluruhan, sebagai hasil pengalamannya sendiri dalami interaksi dalam lingkungannya (Slemanto, 2003:2).

Chaplin dalam Syah, Muhibin (1999:89) mengemukakan bahwa: "Belajar adalah perolehan perubahan tingkah laku yang relative menetap sebagai akibat latihan dan pengalaman.", Skinner, seperti yang dikutip Barlow (1985) berpendapat bahwa: "Belajar adalah suatu proses adaptasi atau penyesuaian tingkah laku yang berlangsung secara progresif", Hizman, berpendapat bahwa: "Belajar adalah suatu perubahan yang terjadi dalam diri organisme (manusia atau hewan) disebabkan oleh pengalaman yang dapat mempengaruhi tingkah laku organisme tersebut."

Sedangkan definisi aktivitas salah satunya menurut pendapat Anwar D. (2005) dalam kamus lengkap Bahasa Indonesia, aktivitas didefinisikan sebagai kegiatan atau kesibukan. Selanjutnya menurut TIM Dosen FIP IKIP Malang (1980) mengungkapkan bahwa manusia adalah merupakan mahluk yang aktif. Keaktifan itu diperlukan untuk dapat memenuhi kebutuhan dan menyesuaikan diri dengan lingkungannya, yang mana 
proses pendidikan adalah merupakan salah satu aktivitas pendidikan.

Sedangkan Pembelajaran berbasis ICT adalah Pembelajaran yang memakai media Teknologi dan Komunikasi (Information, Communication and Technology atau ICT) pada bidang pembelajaran. Guru dengan menggunakan fasilitas elektronika (e), penggabungan antara keduanya disebut pembelajaran melalui elektronik atau e-learning. Dengan demikian, e-Learning atau pembelajaran melalui on-line adalah pembelajaran yang pelaksanaannya didukung oleh teknologi seperti telepon, audio, video, tape, transmisi, atau komputer. Perusahaan Star-Up yang bergerak di dunia pengembangan pendidikan gratis yang berbasis di London dan penggunanya menyebar ke seluruh dunia. Media Quipperschool menyediakan fasilitas materi pelajaran, soal dalam bentuk tugas dan soal ujian yang dilakukan secara online. Dengan demikian, e-Learning atau pembelajaran melalui on-line adalah pembelajaran yang pelaksanaannya didukung oleh teknologi seperti telepon, audio, video, tape, transmisi, atau komputer. Media yang digunakan adalah Quipperschool yang merupakan media $e$ learning berbasis edukatif dengan memanfaatkan jejaring sosial berpusat di Inggris.

Sementara itu aktivitas peserta didik merupakan suatu perbuatan atau kegiatan peserta didik di dalam proses pembelajaran. Aktivitas peserta didik ini seperti memperhatikan penjelasan guru; memperhatikan penjelasan teman dalam kelompoknya, kerja kelompok mengemukakan pertanyaan, menjawab pertanyaan dan partisipasi dalam diskusi kelompok. Dalam penelitian ini, melaksanakan observasi merupakan langkah terkait untuk melihat aktivitas peserta didik selama proses pembelajaran. Hasil belajar menunjukkan seberapa jauh pelajaran telah dikuasai atau dicapai peserta didik. Hasil belajar peserta didik diukur dari ranah kognitif. Aspek kognitif yang akan digali dibatasi pada aspek pengetahuan $\left(\mathrm{C}_{1}\right)$, pemahaman
$\left(\mathrm{C}_{2}\right)$, penerapan $\left(\mathrm{C}_{3}\right)$, dan analisis $\left(\mathrm{C}_{4}\right)$. Pada penelitian ini hasil belajar peserta didik akan dilihat dari tugas kelompok, tugas individu, dan skor akhir ulangan harian.

\section{Metode Penelitian}

Metode yang digunakan dalam penelitian ini adalah metode Penelitian Tindakan Kelas (PTK). Penelitian Tindakan Kelas ini bertujuan untuk memberikan deskripsi/gambaran tentang hasil belajar fisika peserta didik melalui pembelajaran Berbasis ICT (Quipperschool), yang akan dilaksanakan terhadap peserta didik kelas IX-A SMP Negeri 1 Kota Tasikmalaya. Alasan peneliti menggunakan model Penelitian Tindakan Kelas (PTK) karena metode ini merupakan suatu cara penelitian yang berbasis konteks pembelajaran, yang bertujuan untuk memperbaiki dan meningkatkan mutu pembelajaran

Variabel dalam penelitian ini terdiri dari dua, yaitu variable bebas dan variable terikat. Penerapan pembelajaran Berbasis ICT pada pembelajaran materi elektrostatis merupakan variabel bebas, sedangkan hasil belajar peserta didik merupakan variabel terikat. Sudjana, (2005) tentang variabel berpendapat bahwa "Variabel secara sederhana dapat diartikan sebagai ciri dari individu, objek, gejala, peristiwa yang dapat diukur secara kuantitatif ataupun kualitatif." Artinya bahwa dalam penelitian ini ada keterkaitan yang merupakan hubungan saling ketergantungan.

\section{Hasil dan Pembahasan}

Berdasarkan hasil belajar peserta didik untuk setiap siklus dari tugas individu, tugas kelompok, dan ulangan harian diperoleh data seperti pada Tabel 1.

Berdasarkan tabel tersebut dapat dirinci bahwa untuk tugas individu terdapat peningkatan rata-rata skor dari siklus I ke siklus II meningkat sebesar 8,34 dan dari siklus II ke siklus III terdapat peningkatan sebesar 5,03. Untuk rata-rata skor tugas kelompok terdapat peningkatan dari siklus I ke siklus II sebesar 10,00 dan dari siklus II ke siklus III terdapat peningkatan sebesar 2,86. 
Rata-rata ulangan harian terdapat peningkatan dari siklus I ke siklus II sebesar 10,00 dan dari siklus II ke siklus III terdapat peningkatan sebesar 1,38. Untuk nilai akhir terdapat peningkatan dari siklus I ke siklus II sebesar 9,45 dan dari siklus II ke siklus III terdapat peningkatan sebesar 3,10. Hal ini menunjukkan bahwa pembelajaran Berbasis ICT (quipperschool) pada pembelajaran materi Elektrostatis dapat meningkatkan hasil belajar peserta didik kelas IX- A SMP Negeri 1 Kota Tasikmalaya.

Aktivitas belajar peserta didik dalam kelompok mengalami peningkatan, ini terlihat dengan menurunnya aktivitas peserta didik dalam memperhatikan penjelasan guru. Dari siklus I 32,81 \% menurun pada siklus II menjadi $7,81 \%$ dan menurun lagi pada siklus III menjadi $1,56 \%$. Hal ini menunjukkan bahwa peserta didik makin banyak beraktivitas dalam kelompoknya dan ketergantungan pada guru berkurang.

\section{Tabel 1. Rekapitulasi Perolehan Nilai Peserta didik untuk Setiap Siklus}

\begin{tabular}{ccccc}
\hline \multirow{2}{*}{ Siklus } & \multicolumn{3}{c}{ Rerata Skor } & \multirow{2}{*}{ NA } \\
\cline { 2 - 4 } & T. Indv. & T. Kel. & UH & \\
\hline I & 69,55 & 69,72 & 73,58 & 70,89 \\
II & 77,79 & 79,72 & 83,58 & 80,34 \\
III & 82,82 & 82,58 & 84,96 & 83,44 \\
\hline
\end{tabular}

T. Indv. : Tugas Individu

T. Kel. : Tugas Kelompok

UH : Ulangan Harian

NA : Nilai Akhir

Aktivitas memperhatikan penjelasan teman dalam kelompoknya mengalami penurunan dari siklus I 7,81\% mengalami penurunan pada siklus II menjadi $3,13 \%$ dan turun lagi pada siklus III menjadi $1,56 \%$. Artinya waktu yang diperlukan untuk memperhatikan penjelasan teman mengalami penurunan karena masingmasing peserta didik cenderung telah memahami konsepnya. Aktivitas kerja kelompok naik dari siklus I 29,69\% mengalami kenaikan pada siklus II menjadi $39,06 \%$ dan naik lagi pada siklus III menjadi 42,19\%. Hal ini menunjukkan aktivitas kerja kelompok menempati aktivitas terbesar yaitu seperempat dari seluruh waktu pembelajaran yang tersedia.
Aktivitas menjawab pertanyaan dari siklus I 3,13\% mengalami kenaikan pada siklus II menjadi $14,06 \%$ walaupun pada siklus III tidak mengalami kenaikan persentase. Artinya peserta didik mulai memiliki keberanian untuk menjawab pertanyaan. Hal ini terjadi karena peserta didik mulai terbiasa dengan pembelajaran Berbasis ICT (quipperschool) dan peserta didik mulai tidak ragu-ragu mengemukakan ide dan jawaban terhadap permasalahan di kelas pada saat proses pembelajaran berlangsung. Kenaikan persentase pada aktivitas tersebut tidak terlalu signifikan karena waktu yang diperlukan sama, walaupun peserta didik bergantian bertanya atau menjawab tetap tidak lebih dari 3 orang selama pembelajaran berlangsung.

Aktivitas mengemukakan pendapat terdapat peningkatan dari siklus I $1,56 \%$ mengalami kenaikan pada siklus II menjadi 4,69\% dan naik lagi pada siklus III menjadi $6,25 \%$. Artinya peserta didik mulai memiliki keberanian untuk mengemukakan pendapat. Hal ini terjadi karena peserta didik mulai terbiasa dengan pembelajaran Berbasis ICT (quipperschool) dan peserta didik mulai tidak ragu-ragu mengemukakan ide dan pendapatnya terhadap permasalahan pada saat kerja kelompok maupun pada saat proses pembelajaran berlangsung.

Aktivitas partisipasi dalam mengerjakan LKPD mengalami penurunan pada siklus I 14,06\% turun pada siklus II menjadi $9,38 \%$ dan besarnya persentase tetap pada siklus III. Hal ini dikarenakan waktu yang diperlukan untuk mengerjakan LKPD pada setiap pertemuan dalam menyelesaikan soal memerlukan waktu seper enam belas dari waktu pembelajaran dan juga peserta lebih tertarik pada kegiatan diskusi kelompok. Menurut Observer peserta didik sudah aktif dalam mengerjakan LKPD. Begitu pula dengan aktivitas dalam diskusi kelompok terdapat peningkatan dari dari siklus I 6,25\% mengalami kenaikan pada siklus II menjadi 10,94\% dan meningkat kembali pada siklus III menjadi $14,06 \%$. Menurut observer diskusi sudah berjalan 
dengan baik pada siklus II dan siklus III ini.

Berdasarkan hasil perhitungan yang dilakukan terhadap pilihan jawaban angket yang diberikan kepada peserta didik diperoleh rata-rata 4,54, artinya memenuhi kriteria rata-rata pilihan peserta didik lebih dari 3 (tiga). Dengan demikian, respon peserta didik kelas IX-A SMP Negeri 1 Kota Tasikmalaya positif terhadap penerapan Pembelajaran Berbasis ICT (quipperschool) pada pembelajaran materi Elektrostatis.

\section{Penutup}

Berdasarkan hasil penelitian, pengolahan dan analisis data serta pengujian hipotesis tindakan yang telah dilakukan dalam penelitian ini maka simpulan yang diperoleh adalah (1) Penerapan pembelajaran Berbasis ICT (quipperschool) pada pembelajaran materi elektrostatis dapat meningkatkan hasil belajar peserta didik kelas IX-A SMP Negeri 1 Kota Tasikmalaya, (2) Terdapat peningkatan aktivitas siswa kelas IX-A SMP Negeri 1 Kota Tasikmalaya pada pembelajaran materi elektrostatis melalui penerapan pembelajaran Berbasis ICT (quipperschool).

Berdasarkan simpulan penelitian , maka peneliti menyarankan (1) Kepada guru IPA di SMP Negeri 1 Kota Tasikmalaya sebaiknya mencoba menerapkan pembelajaran Berbasis ICT (quipperschool) pada pembelajaran IPA, (2) Kepada kepala sekolah atau pemegang kebijakan dalam bidang pendidikan, diharapkan mensosialisasikan penggunaan penerapan pembelajaran Berbasis ICT (quipperschool) bagi guruguru IPA yang belum memperoleh teori tentang penerapan pembelajaran Berbasis ICT dengan media Quipperschool, (3) Kepada peneliti selanjutnya disarankan untuk mencoba menerapkan metode atau model pembelajaran lainnya pada pembelajaran materi elektrostatis.

\section{Referensi}

Arikunto, S. (2002). Prosedur Penelitian Suatu Pendekatan Praktek. Jakarta: Rineka Cipta.

Degeng, I. N. S. (2005). Media pembelajaran: Universitas PGRI Surabaya

Dimyati, M. (1994). Belajar dan Pembelajaran. Jakarta: Dirjen Dikti Depdikbud.

Dryden, G \& Vos, J. 2003. Revolusi Cara Belajar (The Learning Revolution). Bandung: Kaifa.

Efendi, E. Zhuang, D. Hartono. (2005). Elearning. Konsep dan Aplikasi. Yogyakarta: Andi Offset.

Isjoni \& Firdaus. (2008). Pembelajaran Terkini. Perpaduan Indonesia Malaysia. Yogyakarta: Pustaka Pelajar.

Kasbolah, E.S. Kasihani. (1998). Penelitian Tindakan Kelas. Departemen Pendidikan dan Kebudayaan. Dirjen Dikti Proyek Pendidikan Guru Sekolah dasar.

Means, B. (1993). Using Technology to Support Education Reform. Amerika Serikat. US Government Printing Office.

Sardiman, A.M. (2006). Interaksi dan Motivasi belajar mengajar. Jakarta: Raja Grafindo Persada

Sudjana, Nana (2005). Tuntunan Penyusunan Karya Ilmiah. Bandung: Sinar Baru Algesindo.

Sudjana, N. \& Rivai, A. (2007). Teknologi Pengajaran. Bandung. Sinar Baru Algensindo.

Suryadi, A. (2007). Pemanfaatan ICT dalam Pembelajaran. Jurnal Pendidikan Terbuka dan Jarak Jauh. 8(1):83-98.

Suparman (2007). Meningkatkan Aktivitas \& Hasil Belajar Di Materi Listrik Statik Dengan Pembelajaran Berbasis ICT Pada Kelas IX di SMP Negeri 4 Kendari. Laporan Penelitian Tindakan Kelas: tidak diterbitkan.

Tim Pelatih Proyek PGSM. (1999). Penelitian Tindakan Kelas (Classroom Action Research). Jakarta:Depdiknas. 
Tim Penyusun. (2005). Pedoman Penulisan Laporan Penelitian Tindakan Kelas dan Pedoman Kerja Dewan Bimbingan Laporan Penelitian Tindakan Kelas Fakultas Keguruan dan Ilmu Pendidikan Universitas Siliwangi.Tasikmalaya: Tidak diterbitkan. 